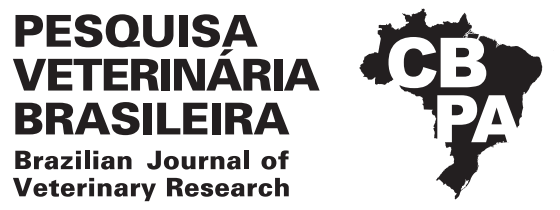

Pesq. Vet. Bras. 39(7):492-498, July 2019 DOI: 10.1590/1678-5150-PVB-6027

Original Article

ISSN 0100-736X (Print)

ISSN 1678-5150 (Online)

\title{
Canine lymphomas diagnosed in southern Brazil from 2000 to 2017: epidemiology and immunophenotype ${ }^{1}$
}

\author{
Ana Carolina B. Coelho ${ }^{2,3}$, Joanna V.Z. Echenique², Bianca S. Lemos' \\ Pablo Estima-Silva ${ }^{2}$, Eliza Simone V. Sallis ${ }^{4}$, Margarida B. Raffi ${ }^{4}$ \\ and Ana Lucia Schild ${ }^{5 *}$ (D)
}

\begin{abstract}
Coelho A.C.B., Echenique J.V.Z., Lemos B.S., Estima-Silva P., Sallis E.S.V., Raffi M.B. \& Schild A.L. 2019. Canine lymphomas diagnosed in the southern Brazil from 2000 to 2017: epidemiology and immunophenotype. Pesquisa Veterinária Brasileira 39(7):492-498. Laboratório Regional de Diagnóstico, Faculdade de Veterinária, Universidade Federal de Pelotas, Campus Universitário s/n, Centro, Pelotas, RS 96010-900, Brazil. E-mail: alschild@terra.com.br

Lymphoma is a neoplasm that originates from solid hematopoietic tissues and is one of the most common tumors in dogs. The goal of the present study was to perform a retrospective study of canine lymphomas diagnosed at the "Laboratório Regional de Diagnóstico", at the "Faculdade de Veterinária" of the "Universidade Federal de Pelotas" (LRD-UFPel) from 2000 to 2017, to determine the epidemiology and anatomical distribution, and to evaluate the histopathological and immunohistochemical aspects of each case according to the adapted Kiel classification. The protocols for necropsies and biopsies in the laboratory were reviewed. Lymphoma was diagnosed in 77 dogs. Approximately 37.7\% (29/77) of affected dogs had no defined breed, while dogs with defined breeds accounted for $58.4 \%$ $(45 / 77)$ of the diagnoses. The occurrence in males (40/77) was slightly higher than that in females (36/77), and the mean age was 8.1 years (1.4-17 years). The most affected age group was between six and 10 years of age with 31 cases $(40.2 \%)$. Regarding the anatomical classification, the multicentric form was the most prevalent, accounting for $71.4 \%(55 / 77)$ of the diagnoses. In 40 cases that immunophenotyping was performed, B-cell lymphomas represented $62.5 \%$ of the diagnoses $(25 / 40)$, while T-cell lymphomas corresponded to $37.5 \%$ of the diagnoses $(15 / 40)$. The degree of malignancy according to the modified Kiel classification was low in $35 \%$ of lymphomas (14/40) and high in $65 \%$ of cases $(26 / 40)$. The multicentric form was more frequent in the region of influence of the LRD-UFPel. Identification of the immunophenotype can improve the quality of life and survival in affected dogs since it allows the most appropriate treatment for each patient.
\end{abstract}

INDEX TERMS: Canine, lymphomas, diagnosis, southern Brazil, epidemiology, immunophenotype, immunophenotyping.

\footnotetext{
${ }^{1}$ Received on November 30, 2018.

Accepted for publication on March 31, 2019.

${ }^{2}$ Graduate Studies Program in Veterinary, Faculdade de Veterinária, Universidade Federal de Pelotas (UFPel), Campus Universitário Capão do Leão, Centro, Pelotas, RS 96010-900, Brazil.

${ }^{3}$ Faculdade de Veterinária, Centro Universitário Ritter dos Reis (UniRitter), Rua Orfanotrofio 555, Alto Teresópolis, Porto Alegre, RS 90840-440, Brazil.

${ }^{4}$ Departamento de Patologia, Faculdade de Veterinária, Universidade Federal de Pelotas (UFPel), Campus Universitário Capão do Leão, Centro, Pelotas, RS 96010-900.

${ }^{5}$ Laboratório Regional de Diagnóstico (LRD), Faculdade de Veterinária, Universidade Federal de Pelotas (UFPel), Campus Universitário Capão do Leão, Centro, Pelotas, RS 96010-900.* Corresponding author: alschild@terra.com.br
}

RESUMO.- [Linfomas caninos diagnosticados na região Sul do Rio Grande do Sul de 2000 a 2017: epidemiologia e imunofenótipo.] 0 linfoma é uma neoplasia com origem nos tecidos hematopoiéticos sólidos e é um dos tumores mais frequentes em cães. 0 objetivo do presente trabalho foi efetuar um estudo retrospectivo dos linfomas caninos recebidos no Laboratório Regional de Diagnóstico, da Faculdade de Veterinária da Universidade Federal de Pelotas (LRD-UFPel) de 2000 a 2017, determinando a epidemiologia e a distribuição anatômica, bem como os aspectos histopatológicos e imuno-histoquímicos de cada caso de acordo com a classificação de Kiel adaptada. Foram 
revisados os protocolos de necropsias e biópsias recebidos no laboratório identificando-se 77 casos de cães com diagnóstico de linfoma. A doença afetou cães sem raça definida em 37,7\% (29/77) dos casos, enquanto os cães com raças definidas tiveram 58,4\% (45/77) dos diagnósticos. A ocorrência em machos (40/77) foi discretamente maior do que em fêmeas (36/77) e a idade média foi de 8,1 anos (1,4-17 anos). A faixa etária mais acometida foi entre seis e 10 anos de idade com 31 casos (40,2\%). Quanto à classificação anatômica a forma multicêntrica foi a mais prevalente atingindo 71,4\% (55/77) dos diagnósticos. Em 40 casos em que a imunofenotipagem foi realizada, os linfomas de células B representaram $62,5 \%$ dos casos (25/40), enquanto os linfomas de células T equivaleram a 37,5\% dos diagnósticos (15/40). 0 grau de malignidade de acordo com a classificação de Kiel modificada foi baixo em $35 \%$ dos linfomas (14/40) e alto em $65 \%$ dos casos $(26 / 40)$. Conclui-se que a forma multicêntrica é mais frequente na região de influência do LRD-UFPel e que a identificação do imunofenótipo pode melhorar a qualidade de vida e dar maior sobrevida aos cães afetados uma vez que permite o tratamento mais adequado para cada caso.

TERMOS DE INDEXAÇÃO: Caninos, linfoma, diagnóstico, Rio Grande do Sul, epidemiologia, imunofenótipo.

\section{INTRODUCTION}

Lymphoma, which is also called lymphosarcoma, is a common hematopoietic neoplasm in dogs and accounts for $7 \%$ to $24 \%$ of all canine tumors and up to $83 \%$ of hematopoietic neoplasms in this species (Vail \& Young 2007, Vail 2010). The etiology of lymphoma has been reported to be multifactorial and includes viral infections, genetic predisposition, and environmental factors (Cunha et al. 2011). Human non-Hodgkin's lymphoma (NHL) has several characteristics in common with canine lymphoma and because of this similarity, the schemes used for morphological classification of human NHL, such as those of the Kiel and Working Formulation, have been used with success by several authors to classify canine lymphoma (Moreno \& Bracarense 2007, Suzano et al. 2010). Both systems classify lymphoma according to the degree of malignancy, and the World Health Organization (WHO) classifies lymphoma anatomically according to its origin as multicentric, mediastinal or thymic, alimentary, cutaneous and extranodal, of which multicentric lymphoma is the most common presentation (Owen 1980).

The large amount of tumor biology information in different neoplastic types in each species requires careful diagnosis and encompasses cellular and molecular characteristics that go beyond the definition of malignancy (Ramos-Vara et al. 2008). Immunohistochemistry (IHC) is an important tool for characterizing neoplastic diseases in humans and has also become important in veterinary medicine. This technique is fundamental in routine diagnostics for identifying different histological types and prognostic factors, directing appropriate treatment for the affected animals, and identifying patients with a higher risk of relapse and fatal course of disease (Capelozzi 2009). In veterinary medicine, there are few studies on the epidemiological, clinical, morphological and phenotype characteristics of lymphoma in dogs (Moreno \& Bracarense 2007).
The objective of the present study was to perform a retrospective study of canine lymphomas diagnosed at the "Laboratório Regional de Diagnóstico", of the "Faculdade de Veterinária" of the "Universidade Federal de Pelotas" (LRD-UFPel) from 2000 to 2017, to determine its epidemiology and anatomical distribution, to describe the histopathological and immunohistochemical aspects of 40 diagnosed cases according to the Kiel classification, and to determine the predominant immunophenotype in dogs in the region of influence of the LRD-UFPel.

\section{MATERIALS AND METHODS}

Records from biopsies and necropsies performed from 2000 to 2017 by the LRD-UFPel were reviewed. Epidemiological information (breed, sex and age), histological descriptions and anatomical locations of the tumors were retrieved. The dogs were grouped by age, as follows: 1) up to two years, 2) from two to five years, 3) older than five years but younger than 10 years, and 4) older than 10 years (Cunha et al. 2011). Regarding the size of the breed, the dogs were divided into giant or large breeds, medium breeds and small breeds. To perform the anatomical classification, the criteria proposed by the World Health Organization (OMS) were used. In addition, 40 cases were selected and histologically reassessed and classified according to the modified Kiel system (Suzano et al. 2010) and were immunophenotypically characterized using immunohistochemical technique. For the detection of immunophenotype B, anti-CD79a antibody (CD79A Protein, Mouse, Recombinant - ECD, Fc Tag - BIOCARE MEDICAL) was used at a dilution of 1:100, and for T-immunophenotype, anti-CD3 antibody (Rabbit Monoclonal, EP41 - IgG BIOCARE MEDICAL) was used at a dilution of 1:100 in 7.2\% PBS solution. Histological sections $3-\mu \mathrm{m}$ thick were mounted on charged slides, were deparaffinized and rehydrated in a xylol and alcohol battery. For endogenous peroxidase blocking, $10 \%$ hydrogen peroxide solution diluted in methanol was added for 20 minutes at room temperature. Antigen retrieval for anti-CD79a was performed using TRIS solution after microwaving for 15 minutes, and for anti-CD3 antigen retrieval, proteinase $\mathrm{K}$ was used for 15 minutes at room temperature. Blocking of nonspecific reactions (background) was performed with $5 \%$ skim milk diluted in $7.2 \%$ PBS for 25 minutes. The sections were covered with the solution containing the antibody and incubated in a humid chamber for 18 hours (overnight) at $4^{\circ} \mathrm{C}$. The sections were incubated with MACH 4 Mouse Probe for 15 minutes at $33^{\circ} \mathrm{C}$ and then incubated with MACH 4 HRPPolymer for 30 minutes at $35^{\circ} \mathrm{C}$, both of which were purchased from BIOCARE MEDICAL (MACH 4 Universal HPR-Polymer Detection System). The chromogen associated detection system (DAB) was applied for approximately 40 seconds. The slides were then sheared with Harris hematoxylin for approximately 15 seconds, washed in distilled water and dehydrated in increasing alcohol gradations, clarified in xylol and mounted with Entellan. For the negative control, $7.2 \%$ nonimmune PBS was used instead of the primary antibody, and as a positive control, unchanged swine tonsils were used. The slides were evaluated under an optical microscope and classified as positive or negative.

\section{RESULTS}

From 2000 to 2017, 77 cases of canine lymphoma were diagnosed in the LRD: 38 in biopsies/organs and 39 in necropsies. Thirty-one ( $40.2 \%)$ dogs were 5 to 10 years-old; $18(23.4 \%)$ were older than 10 years; 17 (22.1\%) were 2 to 5 years-old; and $2(2.6 \%)$ were aged less than 2 years. 
The mean age of the affected dogs was eight years and one month. In nine protocols, the age was not reported. Regarding the sex of dogs affected by the disease, 40 cases (52\%) were observed in males, and 36 cases (47\%) were observed in females; in one case, the sex of the animal was not reported. Out of 77 cases, 45 occurred in dogs with a defined breed, and 29 occurred in dogs with an undefined breed. In three cases, the breed was not recorded in the protocols. Out of the 45 dogs with a defined breed, 22 (48.9\%) were giant or large breeds, 14 (31.1\%) were medium-sized breeds, and 9 (20\%) were small breeds. Regarding the anatomic classification, the multicentric presentation was observed in 55 cases $(71.4 \%)$, followed by the alimentary form in nine cases $(11.7 \%)$, the cutaneous form in seven cases (9.1\%), and extranodal disease in six cases $(7.8 \%)$.

Out of the 40 cases of canine lymphoma selected for immunophenotyping, 21 were from necropsies, and 19 were from biopsies. The course of the disease from the first clinical signs until death or euthanasia was recorded in the protocols of 13 necropsies. Out of these 13 cases, 10 were positive for B cells, eight were multicentric, one was alimentary and one extranodal, and the course varied from three days to three years; in the dog with extranodal lymphoma, the disease duration was three days. Of the three cases that were positive for T cells, all were multicentric, and the course of disease ranged from two weeks to six months. In two biopsies that were sent to the LRD-UFPel and were both positive for $\mathrm{B}$ cells and multicentric, the survival of the affected dog in one case was two years and eight months, and in the other was four weeks. In the patient with the longer disease course, the dog was treated with the protocol indicated for the disease (a combination of cyclophosphamide, vincristine and prednisone for four weeks and maintenance with lomustine for five months). The patient with the duration of disease of one month was not treated.

Forty cases of lymphoma were diffuse, and the number of cases and the histological characteristics (Fig.1A-D), according to the Kiel criteria are presented in Table 1. The degree of malignancy according to the modified Kiel classification was low in $35 \%$ of lymphomas (14/40) and high in $65 \%$ of lymphomas (26/40). According to the results of immunohistochemistry, B-cell lymphomas represented $62.5 \%$ of the cases $(25 / 40)$, while T-cell lymphomas corresponded to $37.5 \%$ of the cases (15/40). Table 2 shows the frequency of the cell types observed
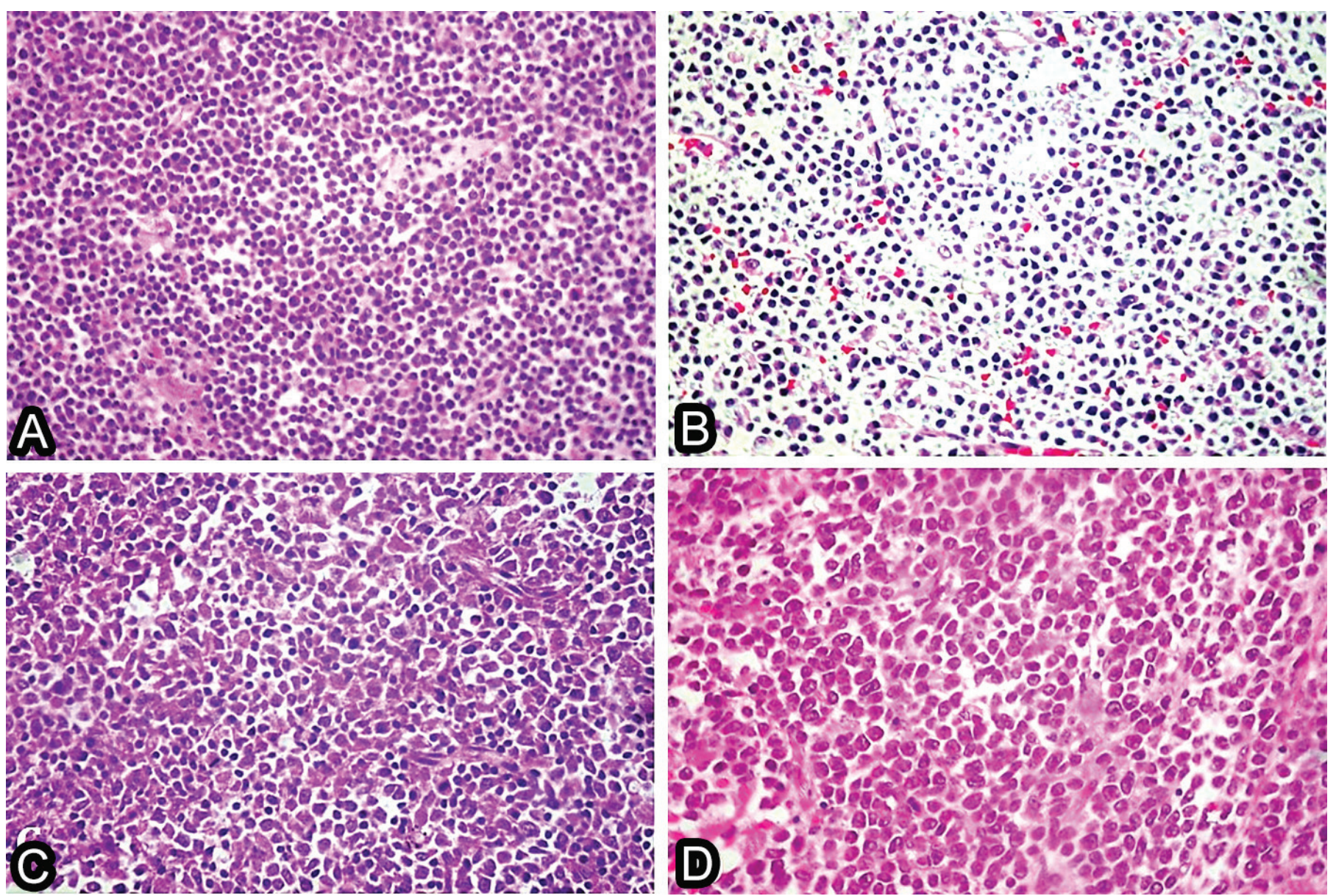

Fig.1. Lymphoma in dog. (A) Lymphocytic lymphoma. Small cells, with small rounded nuclei, dense chromatin and scarce cytoplasm. HE, obj.20x. (B) Centrocytic lymphoma. Small cells with scarce cytoplasm, with small and irregular nuclei, loose to dense chromatin. HE, obj.20x. (C) Centrocytic-centroblastic lymphoma. Two distinct cell groups, small cells similar to the centrocytic type and large cells similar to the centroblastic type. HE, obj.20x. (D) Centroblastic lymphoma. Large cells with slightly basophilic cytoplasm, ranging from scarce to abundant. Rounded nuclei, loose chromatin, with multiple medium size peripheral nucleoli, and mitoses. HE, obj.20x. 
in each case of lymphoma according to the Kiel classification, as well as the immunophenotype of each tumor.

Regarding the anatomical classification of the 40 selected cases, the multicentric form occurred in 65\% (26/40) of dogs with a history of generalized lymphadenopathy; 17 were diagnosed at necropsy, and nine were diagnosed by biopsies. Eighteen dogs were positive for B cells, and eight were positive for T cells. The cutaneous form occurred in $12.5 \%$ $(5 / 40)$ of the dogs, and all of them were positive for T cells; the alimentary form occurred in $12.5 \%$ (5/40) of the dogs, and all of them were positive for B cells; and the extranodal form occurred in 10\% (4/40) of the dogs, with two dogs being positive for B cells (Fig.1A) and two dogs being positive for T cells (Table 2, Fig.2B).

Table 1. Number of cases and histological characteristics of the lymphomas observed according to the criteria of the modified Kiel system

\begin{tabular}{|c|c|c|}
\hline Modified Kiel system & Number of cases & Histological characteristics \\
\hline \multicolumn{3}{|l|}{ Low grade of malignancy } \\
\hline Lymphocytic & 2 & Small cells, with small rounded nuclei, dense chromatin and scarce cytoplasm. \\
\hline Centrocitic & 4 & $\begin{array}{l}\text { Small cells with scarce cytoplasm, with small and irregular nuclei, loose to dense chromatin, and } \\
\text { nucleolus present or absent. }\end{array}$ \\
\hline Centrocitic-centroblastic & 8 & $\begin{array}{l}\text { Two distinct cell groups, small cells similar to the centrocytic type and large cells similar to the } \\
\text { centroblastic type. }\end{array}$ \\
\hline \multicolumn{3}{|l|}{ High degree of malignancy } \\
\hline Immunoblastic & 9 & $\begin{array}{l}\text { Cells of medium to large cytoplasm, ranging from abundant to sparse, round to oval nucleus, } \\
\text { vesicular chromatin and prominent and central nucleolus, and the many mitotic figures. }\end{array}$ \\
\hline Lymphoblastic & 3 & $\begin{array}{l}\text { Rounded, small to medium-sized cells with scanty cytoplasm, with a clear alo around cells, } \\
\text { rounded nuclei, dense chromatin and mitotic figures. }\end{array}$ \\
\hline Anaplasic & 5 & $\begin{array}{l}\text { Large and pleomorphic cells with slightly basophilic cytoplasm, large, rounded and irregular } \\
\text { nuclei, loose chromatin and mitotic figures. }\end{array}$ \\
\hline
\end{tabular}

Fonte: Suzano et $a l .2010$

Table 2. Histological and immunuhistochemical classification of 40 cases of canine lymphomas, age, sex and anatomical location

\begin{tabular}{|c|c|c|c|c|c|c|c|c|}
\hline \multirow{2}{*}{ Lymphoma subtypes classification } & \multirow{2}{*}{$\begin{array}{c}\text { Number of } \\
\text { cases }\end{array}$} & \multirow{2}{*}{$\begin{array}{c}\text { Average age } \\
\text { (years) }\end{array}$} & \multicolumn{2}{|c|}{ Sex } & \multicolumn{4}{|c|}{ Anatomical location } \\
\hline & & & $\mathrm{M}$ & $\mathrm{F}$ & Mt & $\mathrm{Al}$ & $\mathrm{Ct}$ & Ex \\
\hline B Cell lymphoma & 25 & & & & & & & \\
\hline Low grade of malignancy & 10 & & & & & & & \\
\hline Lymphocytic & 1 & 1 & & 1 & 1 & & & \\
\hline Centrocytic & 2 & 9.5 & 2 & & 2 & & & \\
\hline Centrocytic-centroblastic & 7 & 7.9 & 6 & 1 & 5 & 2 & & \\
\hline Immunoblastic & 6 & 10.2 & 2 & 4 & 3 & 3 & & \\
\hline Lymphoblastic & 1 & 7 & 1 & & & & & 1 \\
\hline Anaplasic & 4 & 7.3 & 1 & 3 & 3 & & & 1 \\
\hline T Cell lymphoma & 15 & & & & & & & \\
\hline Centrocitic-centroblastic & 1 & 9 & & 1 & 1 & & & \\
\hline High degree of malignancy & 11 & & & & & & & \\
\hline Centroblastic & 5 & 7 & 3 & 2 & 4 & & & 1 \\
\hline Immunoblastic & 3 & 7.7 & 1 & 2 & & & 3 & \\
\hline Lymphoblastic & 2 & 13 & 1 & 1 & 1 & & & 1 \\
\hline Anaplasic & 1 & 2.5 & & 1 & & & 1 & \\
\hline TOTAL & 40 & & 20 & 20 & 26 & 5 & 5 & 4 \\
\hline
\end{tabular}

$\overline{\mathrm{M}}=$ male, $\mathrm{F}=$ female, $\mathrm{Mt}=$ multicentric, $\mathrm{Al}=$ alimentary, $\mathrm{Ct}$ = cutaneous, $\mathrm{Ex}=$ extranodal . 


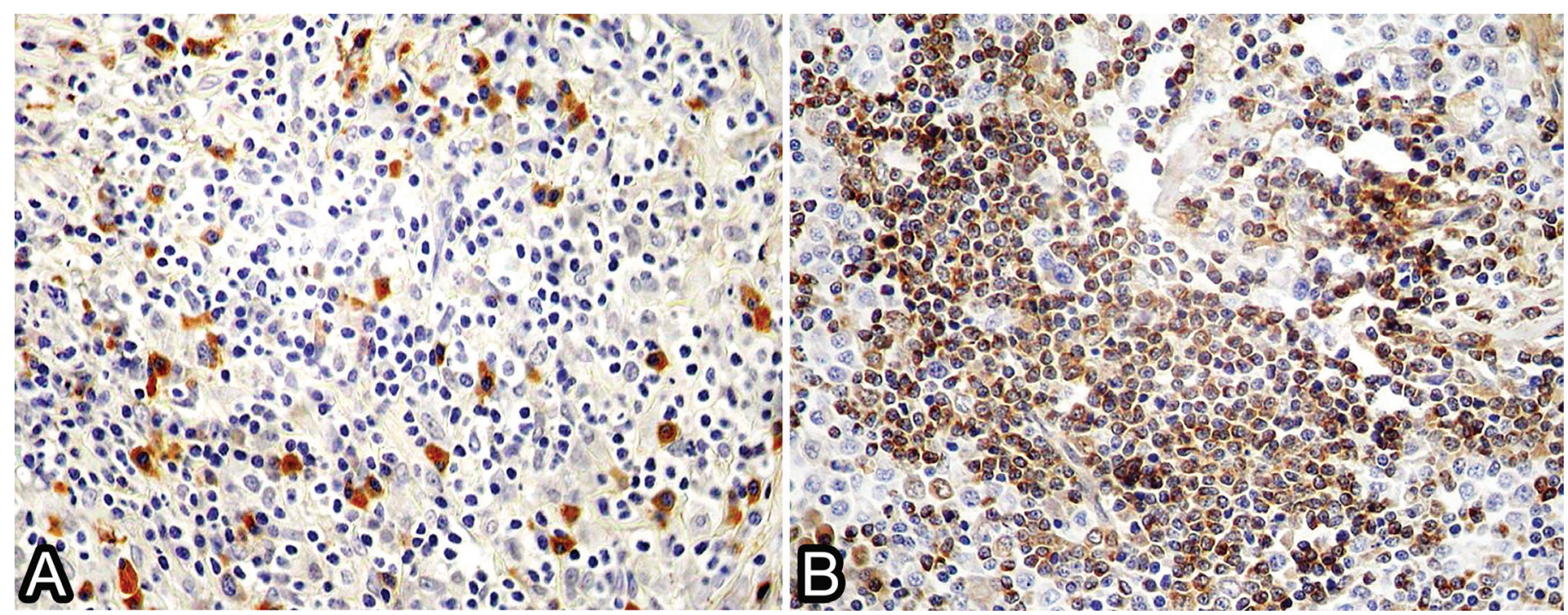

Fig.2. Lymphoma in dog. (A) Immunoblastic lymphoma positive for anti-CD79a antibody (B cell). IHC, obj.20x. (B) Centrocytic-centroblastic lymphoma positive for anti-CD3 antibody (T-cell). IHC, obj.20x.

\section{DISCUSSION}

In the present study, 29 dogs with lymphoma had no defined breed, and 48 patients were of various breeds, with Rottweilers being the most affected dog breed. In other reports, it has been shown that breeds, such as Rottweilers, Boxers, German Shepherds, Cocker Spaniels and Poodles, develop lymphoma more frequently than other dog breeds (Cardoso et al. 2003, Moreno \& Bracarense 2007, Cunha et al. 2011). If we consider the individual breed, the incidence of lymphoma in dogs with an undefined breed was much higher than in those with defined breeds. It is estimated that in the municipality of Pelotas, where most of the dogs in this study came from, that there are approximately $66,700 \mathrm{dogs}$, of which approximately $80 \%$ have no defined breed or are crossbred (Prefeitura Municipal de Pelotas 2012). This could justify the large number of cases in undefined breed dogs.

It was observed that sex apparently does not interfere with the occurrence of lymphoma, which has also been mentioned by other authors (Cunha et al. 2011), although there have been reports of a predisposition to lymphoma in males (Fighera et al. 2006, Moreno \& Bracarense 2007, Gavazza et al. 2009).

The mean age of dogs affected by lymphoma was eight years, and the highest prevalence of the disease occurred in middle-aged dogs. In a similar study, in the central region of Rio Grande do Sul, the authors observed a tendency to develop lymphoma in elderly animals (Fighera et al. 2006). On the other hand, in a study conducted in the North of Paraná, the age group of dogs most frequently affected by the disease was between two and five years of age (Moreno \& Bracarense 2007). This age group was also the most affected in a study carried out in the United States (Teske 1994). These differences suggest that there is no age pattern for the occurrence of lymphomas in dogs; however, animals less than 24 months of age are rarely affected.

According to the anatomical classification, the multicentric form was the most frequently diagnosed, accounting for $71.4 \%$ of the cases. In other studies, it has been demonstrated that the multicentric form is the most frequent form, with percentages higher than $80 \%$ (Teske 1994, Ponce et al. 2010, Neuwald et al. 2014). The high degree of malignancy observed in most lymphomas (65\%) in this study has also been observed by other authors (Teske et al. 1994, Fournel-Fleury et al. 2002, Suzano et al. 2010, Ponce et al. 2010). These findings demonstrate that the behavior of lymphoma with respect to its anatomical location and malignant potential are similar regardless of the region of the study. On the other hand, in terms of the cellular origin, there appears to be a regional or geographical influence that interferes with the cell types of canine lymphoma (Teske et al. 1994, Fournel-Fleury et al. 2002). In the present study, most of the diagnosed lymphomas were B-cell lymphomas (62.5\%), and in a similar study carried out in São Paulo, the most frequent type was T-cell lymphoma, which accounted for $60.2 \%$ of cases (De Moura et al. 2001). These differences may be related to geographical differences. In phenotype studies performed in man, it has been shown that in European countries and the United States, the most frequent phenotype is the B-cell phenotype, with the T-cell phenotype occurring in only $12 \%$ of cases. In Japan, this percentage increases to 50\% (Fournel-Fleury et al. 2002). Geographic differences may influence the immunophenotype of lymphomas in man, which can be extrapolated to dogs (Fournel-Fleury et al. 2002). However, in the State of São Paulo, in a study of the immunophenotypes of lymphomas in humans, a predominance of B-cell lymphoma was found (Gouveia et al. 2011), whereas in a study in dogs, also in São Paulo, T-cell lymphoma was predominant. Ponce et al. (2010) observed $35.4 \%$ of T-cell lymphomas in dogs and suggested that this percentage may be related to the greater number of skin biopsies performed, all with a T-cell immunophenotype. In the present study, out of seven skin samples with a diagnosis of lymphoma, five were submitted for immunohistochemistry to determine the immunophenotype, and all originated from T cells; however, in the LRD case, the skin samples did not outperform the other materials sent for diagnosis, which ruled out the influence of anatomical location on the percentage of T-cell lymphomas in the dogs of this study. 
In the 13 cases of lymphoma in dogs that were diagnosed at necropsy, considerable variation was observed in the duration of the disease, independent of immunophenotype. During the advanced stage of the disease, regardless of the immunophenotype, the course of disease is rapid (Machicote \& González 2008). In four cases of multicentric lymphoma that were positive for B cells, considering that the immunophenotype that is less aggressive, the evolution was less than one week, and in one case of multicentric T-cell lymphoma, which is more aggressive, the observed course of disease was two weeks. It should be noted that the information on the treatment of these animals was not available, and treatment should be considered since it may influence the survival time of the animals. Lymphomas, although highly heterogeneous, are considered to be responsive to chemotherapy. However, in dogs, survival of more than one month is not frequent in untreated animals (MacEwen 1990). This suggests that these five dogs were not treated for the disease. In two diagnoses made by biopsy, in which the protocol provided information on the survival time of dogs, it was found that one of the dogs that were treated with chemotherapy survived for two years, and the other dog that did not undergo chemotherapy survived for a month. In a study of 147 dogs with lymphoma, the mean survival time with complete or partial regression of increases in lymph node volume was 265 days (MacEwen et al. 1987). Most likely, the efficiency of chemotherapy is directly associated with the immunophenotype of lymphoma, which indicates that detection of immunophenotype by immunohistochemistry, is necessary considering the maintenance and quality of life of the pets affected by the disease. The extranodal form is rare in dogs (Jacobs et al. 2002), and in the present study, three of the four cases that were submitted for immunophenotyping were from biopsies and were be classified as multicentric if other organs were involved. The incidence of mediastinal lymphoma has been reported to be low in some studies (Sequeira et al. 1999, Fournel-Fleury et al. 2002) and relatively high in others (Jacobs et al. 2002, Cardoso et al. 2003). In the present study, no cases of mediastinal lymphoma were diagnosed.

The determination of the immunophenotype of lymphoma is of undeniable importance, since it allows detailed diagnosis and prognosis and directs the choice of a more appropriate treatment (Horta et al. 2012). In a study by Kiupel et al. (1999) using the same antibodies from the present study, it was demonstrated that the determination of the immunophenotype in dogs with lymphoma was important for the prognosis of survival, indicating that dogs with B-cell lymphomas, which are less aggressive, were those with a longer survival time (Teske et al. 1994). In the present study, the percentage of tumors with a T-cell immunophenotype and a high degree of malignancy based on morphology was greater $(73 \%)$ than that of low malignancy (27\%). Apparently, from these results, it is possible to corroborate the observations made by Teske et al. (1994), who suggested that T-cell lymphomas always have a high degree of malignancy, independent of cell morphology. In addition, cutaneous lymphoma can be considered to be T-cell lymphoma in origin, and treatments directed to this cell type should be performed when phenotyping is not possible.

\section{CONCLUSIONS}

The results of the present study demonstrated that canine lymphoma presents mostly immunophenotype B and is multicentric, considering the region of influence of the LRD-UFPel.
In cases of cutaneous lymphoma, when it is impossible to perform the phenotyping, treatment protocols for tumors originating from $\mathrm{T}$ cells, seems to be the most appropriate.

Conflict of interest statement.- The authors declare no conflict of interest.

\section{REFERENCES}

Capelozzi V.L. 2009. Role of immunohistochemistry in the diagnosis of lung cancer. J. Bras. Pneumol. 35(4):375-382. <http://dx.doi.org/10.1590/ S1806-37132009000400012><PMid:19466276>

Cardoso M.J.L., Machado L.H.A., Rocha N.S., Moutinho F.Q. \& Ciampolini P. 2003. Linfoma canino: revisão de cinquenta e quatro casos. Biosci. J. 19(3):131-142.

Cunha F.M., Silveira L.M.G., Xavier J.G., Allegretti L. \& Bovino E.E. 2011. Linfoma multicêntrico em Canis familiaris (cão doméstico): estudo retrospectivo de 60 casos, entre agosto de 2009 e dezembro de 2010, no município de São Paulo-SP. J. Health Sci. Inst. 29(4):209-301.

Moura V.M.B.D., Sequeira J.L., Amorim R.L. \& Bandarra E.P. 2001. Imunofenotipagem dos linfomas caninos em tecido incluído em parafina. Revta. Educ. Contin CRMV-SP 4(3):71-75.

Fighera R.A., Souza T.M., Rodrigues A. \& Barros C.S.L. 2006. Aspectos clinicopatológicos de 43 casos de linfoma em cães. MedveP, Revta Cient. Med. Vet. Peq. Anim. Estim. 4(12):139-146.

Fournel-Fleury C., Ponce F., Felman P., Blavier A., Bonnefont C., Chabanne L., Marchal T., Cadore J.L., Goy-Thollot I., Ledieu D., Ghernati I. \& Magnol J.P. 2002. Canine T-cell lymphomas: a morphological, immunological, and clinical study of 46 new cases. Vet. Pathol. 39(1):92-109. <http://dx.doi. org/10.1354/vp.39-1-92><PMid:12102223>

Gavazza A., Sacchini F., Lubas G., Gugliucci B. \& Valori E. 2009. Clinical, laboratory, diagnostic and prognostic aspects of canine lymphoma: a retrospective study. Comp. Clin. Pathol. 18(3):291-299. <http://dx.doi. org/10.1007/s00580-008-0799-y>

Gouveia G.R., Siqueira S.A., Chamone D.A. \& Pereira J. 2011. Prevalence of non-Hodgkin lymphomas in São Paulo, Brazil. Revta Bras. Hematol. Hemoter. 33(4):317-322. <http://dx.doi.org/10.5581/1516-8484.20110085> $<$ PMid:23049326>

Horta R.S., Costa M.P., Lavalle G.E., Araújo R.B. \& Cassali G.D. 2012. Fatores prognósticos e preditivos dos tumores caninos definidos com auxílio da imuno histoquímica. Ciência Rural 42(6):1033-1039. <http://dx.doi. org/10.1590/S0103-84782012000600013>

Jacobs R.M., Messick J.B. \& Valli V.E. 2002. Tumors of the hemolymphatic system, p.119-198. In: Meuten D.J. (Ed.), Tumors in Domestic Animals. 4th ed. Iowa State Press, Ames.

Kiupel M., Teske E. \& Bostock D. 1999. Prognostic factors for treated canine malignant lymphoma. Vet. Pathol. 36(4):292-300. <http://dx.doi. org/10.1354/vp.36-4-292><PMid:10421095>

MacEwen E.G. 1990. Spontaneous tumours in dogs and cats: models for study of cancer biology and treatment. Cancer Metastasis Rev. 9(2):125-136 <http://dx.doi.org/10.1007/BF00046339><PMid:2253312>

MacEwen E.G., Hayes A.A., Matus R.E. \& Kurzman I. 1987. Evaluation of some prognostic factors for advanced multicentric lymphosarcoma in the dog: 147 cases (1978-1981). J. Am. Vet. Med. Assoc. 190(5):564-568. $<$ PMid:3558097>

Machicote G. \& González J.L. 2008. Linfoma Cutáneo. Clin. Vet. Peq. Anim. 28(1):31-37.

Moreno K. \& Bracarense A.P.F.R.L. 2007. Linfoma canino de células T: aspectos epidemiológicos, clínicos e morfológicos de 38 casos. Braz. J. Vet. Res. Anim. Sci. 44(Suppl.):103-110. <http://dx.doi.org/10.11606/issn.1678-4456. bjvras.2007.26597> 
Neuwald E.B., Teixeira L.V., Conrado F.O., Silva M.O.D., Hlavac N.R.C. \& González F.H.D. 2014. Epidemiological, clinical and immunohistochemical aspects of canine lymphoma in the region of Porto Alegre, Brazil. Pesq. Vet. Bras. 34(4):349-354. <http://dx.doi.org/10.1590/S0100-736X2014000400009>

Owen L. 1980. TNM Classification of tumors in domestic animals. World Health Organization, Geneva, p.46-47.

Prefeitura Municipal de Pelotas 2012. Projeto de Castração por Bairros, Anexo III. Prefeitura Municipal de Pelotas, Pelotas, RS. Available at <http:// www.pelotas.com.br/noticia/centro\%20de\%20zoonoses> Accessed on Oct. 9, 2018.

Ponce F., Marchal T., Magnol J.P., Turinelli V., Ledieu D., Bonnefont C., Pastor M., Delignette M.L. \& Fournel-Fleury C. 2010. A morphological study of 608 cases of canine malignant lymphoma in France with a focus on comparative similarities between canine and human lymphoma morphology. Vet. Pathol.47(3):414-433. <http://dx.doi.org/10.1177/0300985810363902> <PMid:20472804>

Ramos-Vara J.A., Kiupel M., Baszler T., Bliven L., Brodersen B., Chelack B., Czub S., Del Piero F., Dial S., Ehrhart E.J., Graham T., Manning L., Paulsen D., Valli V.E. \& West K. 2008. Suggested guidelines for immunohistochemical techniques in veterinary diagnostic laboratories. J. Vet. Diagn. Invest. 20(4):393-413. <http://dx.doi.org/10.1177/104063870802000401> $<$ PMid:18599844>
Sequeira J.L., Franco M., Bandarra E.P., Figueiredo L.M.A. \& Rocha N.S. 1999. Características anatomoclínicas dos linfomas caninos na região de Botucatu, São Paulo. Arq. Bras. Med. Vet. Zootec. 51(3):245-250. <http://dx.doi. org/10.1590/S0102-09351999000300008>

Suzano S.M.C., Sequeira J.L., Rocha N.S. \& Pessoa A.W.P. 2010. Classificação citológica dos linfomas caninos. Braz. J. Vet. Res. Anim. Sci. 47(1):47-54. <http://dx.doi.org/10.11606/issn.1678-4456.bjvras.2010.26848>

Teske E., Wisman P., Moore P.F. \& Van Heerde P. 1994. Histological classification and immunophenotyping of canine Non-Hodgkin's lymphoma. Unexpected high frequency of T-cell lymphomas with B-cell morphology. Exp. Hematol. 22(12):1179-1187. <PMid:7925781>

Teske E. 1994. Canine malignant lymphoma: a review and comparison with human non-Hodgkin's lymphoma. Vet. Q. 16(4):209-219. <http://dx.doi. org/10.1080/01652176.1994.9694451><PMid:7740746>

Vail D.M. 2010. Hematopoietic tumors, p.2148-2158. In: Ettinger S.J. \& Feldman E.C. (Eds), Textbook of Veterinary Internal Medicine: diseases of the cat and dog. 7 th ed. W.B. Saunders, St Louis.

Vail D.M. \& Young K.M. 2007. Canine lymphoma and lymphoid leukemia, p.699-733. In: Withrow S.J. \& Vail DM. (Eds), Withrow and MacEwen's Small Animal Clinical Oncology. 4th ed. W.B. Saunders Elsevier, Missouri. 